\title{
THE HLSTOIOGICAL STUDY OF THE MUCOUS MEMBRANE OF THE TPHENOIDAL SINUS, COMPARING WITH THAT OF THE OTHER SINUSES IN CHRONIC SINUSITIS.
}

By

\author{
N. TAKASUKA, M.D.
}

\section{From the Department of oto-rhino-laryngology, Nagasaki University School of Medicine. Director: Prof. T.Goto}

In 53 cases of chronic sinusitis, the mucous mombrane of the sphenoidal, ethmoidal and maxillary sinuses were histologically studied. The findings of these sinuses were compared each othey to find the histologic characteristics of the mucous membrane in the chronic sphenoidal sinusitis.

The histologic changes of the mucous membrane of thesese sinuses were classified into the following groups:

The maxillary sinus

The minimal type 4 cases $7.5 \%$

The fibrous type 3 cases $5.6 \%$

The fibrous-infiltrative type 15 casas $28.3 \%$

The infiltrative type 10 cases $18.9 \%$

The edematous type 2 cases $3.8 \%$

The edematous-infiltrative type 19 cases $35.9 \%$

The ethmoidal sinus

The minimal type 14 cases $26.4 \%$

The fibrous type 4 cases $7.5 \%$

The fibrous-infiltrative type 9 cases $17.0 \%$

The infiltrative type 2 cases $3.8 \%$

The edematous type 8 cases $15.1 \%$

The sphenoidal sinus

The minimal type 14 cases $26.4 \%$

The fibrous type 9 cases $17.0 \%$

The fibrous-infiltrative type 17 cases $32.1 \%$

The infiltrative type 2 cases $3.8 \%$

The edematous type 3 cases $5.6 \%$

The edematous-infiltrotive type 8 cases $15.1 \%$

From these results the author consluded that in chronic sphenoidal sinusitis, the fibrous type or fibrous-infiltrative type were more frequently seen than in the other two sinuses.

It might be said that the mucous membrane of the sphenoidal sinus shows more fibrotic reaction than the other two sinuses in the chronic sinusitis. 


\title{
慢性副鼻腔炎における蝶形骨洞粘膜の病理組織学的 所見及び他洞との比較
}

\author{
長崎大学医学部耳释咽喉科学教室（主任：後臊敏郎教授） \\ 研究生 高須賀 信 太
}

蝶形骨洞はもつとも深部にあつて，上㖽洞，篩骨蜂 架，前頭洞に比軟して手術の対照とされることが少な く，手術々式の上からも特に取り上げられて来なからた

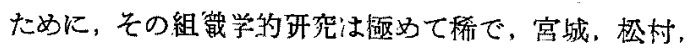
後藤 (敏)，竹本等により発表されているのみである.

慢性副鼻腔炎において洞形骨洞の粘膜が他の副鼻腔の 粘膜に比軟していかなる特徽のある変化を示すかという ことは，副鼻腔炎の病因論を考える上のみでなく手術の 適応を決める上からも必要なことである。

著者は幸に江上世:の提供によつて蝶形骨洞とともに同 一例についての上顎洞及び篣骨䗋集の粘膜 53 側を観察 することができた，これらの観察によつて楼形骨洞の粘 膜の病変の状態を知ることができ，その治療を考える上 にる参考になると思われる所見を得たので報告する。

\section{1. 蝶形骨洞粘膜の病変について}

a) 䉼膜基質の変化について

上顎洞，節骨蜂窠，蝶形骨洞の病変を比較するため に，各洞の粘膜固有層に括いて，結合織線維の增殖の状 態, 浮腫の程度及び粓膜の肥厚の程度について, その基 準になる点を棌わて，各々の病变を観察した。

結合織線維の堌殖の程度としては結合織線維の增殖が 極めて強く，粘膜基質がほとえど緻密な線維で満されて 線維の間吵に浮腫の存在を認め難い例を（H）とし, 線 維が少なく閑慢性の浮腫が認められるむの, 又は線維間 に高度の浮腫が認められる例を(一)とし，その間の段

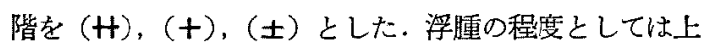
に述へた程度に浮腫が強い例を（H）とし，緻密な線維
が增殖して浮腫の認め難い例を（一）とした。その間の

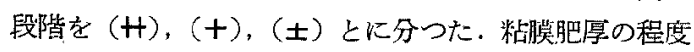
は浮厓性腫掁でも線維性肥厚の埸合でる，正常の嬮さと 思われる粘膜（手術時肥厚を認められなかつた紙状の粘 膜)を(一)とし，これよりほ心゙10倍以上も肥厚してい ると思対れるものを（H）とした，浸潤度については基

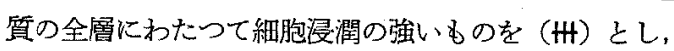

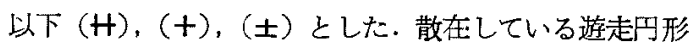
細抱がやや增加している程度を（土）とし，それ以下を （一）とした．以上の基準で 3 種の副鼻腔の粘膜の病变 を分類すると（表1）に示す如くである。

細胞浸潤の程度は上顎洞の粈膜が最も強い、これは臨 床的にも上顎洞が最も病変が強いことから当然のことい 思われる、節骨蜂巢と蝶形骨洞はほさ同じ程度である が，浸潤の强い例は蝶形骨洞の粓膜に僅かに多く，軽度 の浸䍿は笽骨蜂窠の粘膜に多い。

粘漠の肥厚は洞の形態が異るので同じ基集では述べら れないが，やはり病変の強い上顎洞粈膜に郝いて著明で ある、斾骨蜂菒と蝶形骨洞とは同じ程度である.

結合織線維の增殖は蝶形骨洞が最も強々上㖽洞一節骨 蜂爣の順序となつているが，蝶形骨洞の糊莫においては 肥厚は著明でないのに粘膜基質内に結合織線維が密に集 合している例が多いここの著明な線維の堌殖が蝶形骨洞 の粘膜の病変の一つの特徵と思われる.

浮腫の程度は逆に上顎洞と篩骨䗋巢に強く蝶形骨洞の

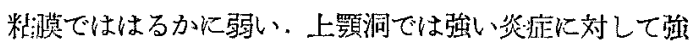
い浮腫性の反応を呈するむのとしても, 同程楚の炎症所

第 1 表各副䶊腔粘膜の病变の傾向

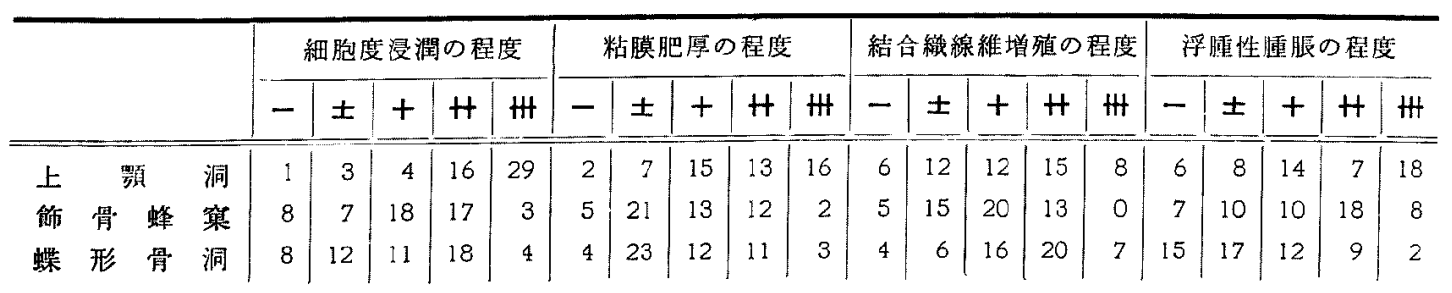


見の蝶形骨洞と篩骨蜂笨とに执いて，粘膜基質に線維の 增䧻と浮腫の傾向とが互に相反した結果として認められ るのは興味ある点と思われる。これは小蜂笨の集合であ る管骨蜂窂と，洞の形態を保つている蝶形骨洞の持つ局 所的な素因によるものと思われる。

蝶形骨洞の炎症の程度については著者の臨床例の統計

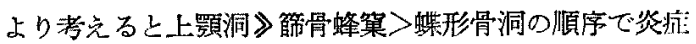
像は軽くなつている。

b) 粘膜症型について

（表 1) に示す上らに結命織線維の增殖，浮蕾の程度， 粘膜の肥厚，細胞浸㵎の所見を基準として，各例を浮缠 型, 浮腫漫潤型, 線維型, 線維浸潤型及び浸潤が極めて 強く粘膜基質がほとんど肉芽様所見を呈している例を浸 潤型とし, 更にこれとは反対以浸潤及び線維の增殖も軽 度で若い結合織線維で構成された結合織網がまだlocker であるが，浮腫もほとんど認められず，従つて粘膜も薄 く病妿の特徽が現れていない軽度の例を軽症型として分 類すると（表 2) に示す結果を得た．併記している前頭 洞糊膜の病型は著者が95 例について同様の規淮で分類 し、先に発表したものである、浸潤が極わて強く、粘膜 肥厚も著明な上颚洞を除く他の3 種の副鼻腔では軽症型 が約 $1 / 4$ をを占めている.蝶形骨洞の特徵として粘膜基 梊の変化に括いて結合繶線維の增殖が強いことを挙げた が，との結果として，線維型，線維浸溜型の例が多い。 軽症型において子蝶形骨洞の粘膜では結合䋨秧が密で線 維細胞が多く、線維の增殖の程度も(H) 飞近いと思わ れるものがあり，線維型と篇密に分類するのが困難であ つた例が多かつた。

第 2 表各副與膑粘膜の病型

\begin{tabular}{|c|c|c|c|c|c|}
\hline 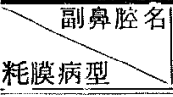 & 上 顎 洞 & 飾骨蜂率 & 蝶形骨洞 & 計 & 前頭洞 \\
\hline 柽 症 型 & $4(7.5 \%)$ & $14(26$ & $14(26,4 \%)$ & 32 & $(23$ \\
\hline 線 維 型 & $3(5.6 \%)$ & $4(7.5 \%)$ & $9(17.0 \%)$ & 16 & (1) \\
\hline 楾䧽浸潤型 & $15(28.3 \%)$ & $9(17.0 \%)$ & $17(32.1 \%)$ & 42 & $\%)$ \\
\hline 浸 洞 型 & $10(18.9 \%)$ & $2(3.8 \%)$ & $2(3,8 \%)$ & 14 & $(6.3 \%)$ \\
\hline 棌睡浸潤型 & $19(35.9 \%)$ & $16(30.2 \%)$ & $8(15.1 \%)$ & 42 & $(35.8 \%)$ \\
\hline 棌 腫 型 & $2(3.8 \%)$ & $8(15.1 \%)$ & $3(5.6 \%)$ & 13 & $(3.1 \%)$ \\
\hline & (0) & 53( & & & $(100 / \%)$ \\
\hline
\end{tabular}

各洞の粘膜の反応の性格を見るために, 線維型と線維 浸渥型の例を線維群とし, 浮腫型之浮腫浸搌型の例を浮 腫群として分類すると（表3）に示寸結果を得た。蝶形
骨洞では線維群の例が多数であるのが特徽ある所見であ

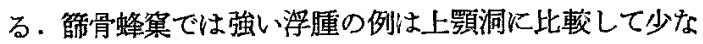
いのであるが，中等度の浮腫を示すものが多いために浮 腄群が多い秸果となつた。

\section{第3 表 各副蜜腔粘膜病型の慔式図}
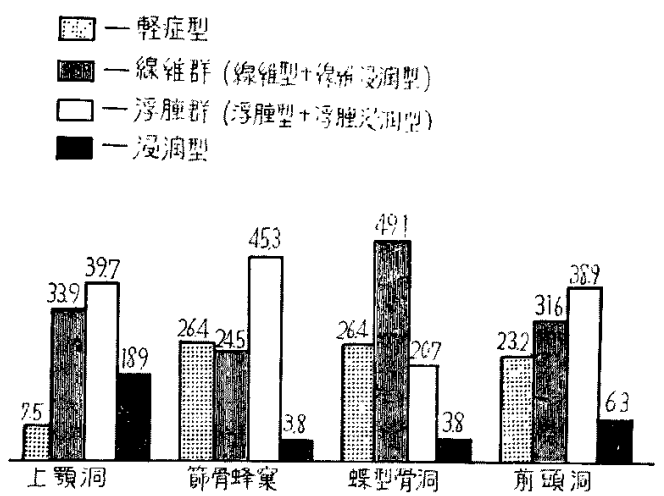

c）蝶形骨洞粘膜の上皮の変化について

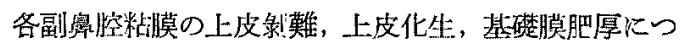

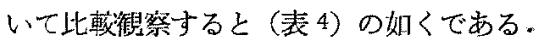

第 4 表上皮 9 変化

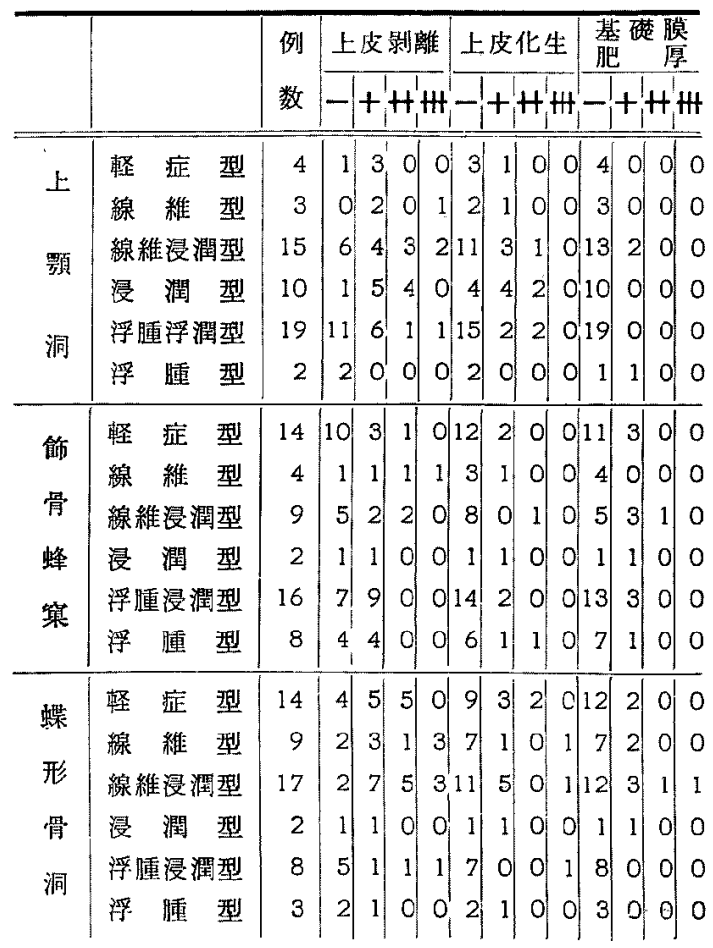


上皮剝離は蝶形骨洞において最す著明である。これは 奥内手術のために手術時の機栈的損傷を受けることが多

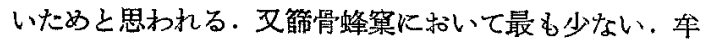
田は節骨蜂窒粘膜では上皮煣難が少ないことを举げて強 度の浸潤が少ないことを原因としている，䟝難部位は粘 膜突出部に多いことは諸家の発表と同じである.

上皮化生は Oppikofer，车田，湯地仙よると炎泟の程 度に比例するるのであるとされている，著者の例では粘 膜上皮が強く剥離したものを除外すると，上顎洞では 49 例中 16 例 $(32.9 \%)$, 節骨蜂窂では 52 例中 9 例 (17.3 \%), 蝶形骨洞では 48 例中 16 例 (33.3\%) であつた。 化生した上皮は立方上皮又は扁平化した立方上皮が最も 多い，約 $1 / 3$ の例では扁平化した立方上皮が石垣状に重 畳した例を認めるが，完全な重層扁平上皮は認められな からた.

基喷膜肥厚は研究者により存在する例が異り，その存 在意義についてるはつきり結論がない，著者の例では上 顎洞では 49 例中 1 例，節省蜂笨では 52 例中 12 例，蝶 杉骨洞では 48 例中 10 例に認められ，浸潤の強さとの比 例る見られず，又アレルギー反応之関保しているとも見
られなかつた。

d）蝶形骨洞粘膜の腺組織の变化について

各洞粘膜について，腺增殖，腺胞执大，腺璓維，腺上 皮经性, 粘液变性, 腺周囲絸胞浸潤. チステ形成の 7 項 目に分つて観察した（表 5)。

蝶形骨洞絬膜には腺組織の認められない,例が多洞に較 べて多い，特柽症型，線維群の例に多く認められた。 この型の例では腺組織が認められる例でも上皮变性，腺 雄縮等の退行性変性の強い例が比較的多く認められる。 腺增殖は他の洞に 比較して遥加に少ない，又程度も軽

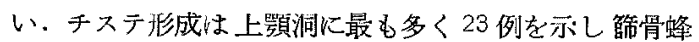
案では20 例，蝶形骨洞では僅が 11 例で著明な形成は 見られない。

e）蝶形骨洞の血管の变化について

一般に血管の滛化は上顎洞粘膜に強く，病型別には浮 腫型より浸潤型に強いとされている。著者の例では（表 6) に示すよらに，充血及び毛細管新生は上顎洞で著明 で浸潤の強い例に多い，血管壁の肥厚は增殖性变化の強 い線維腫の例行いて著明である、浮腫群の例では梁置 の線維兽では見られるが，固有層では少ない。この肥厚

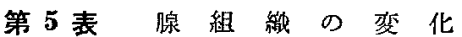

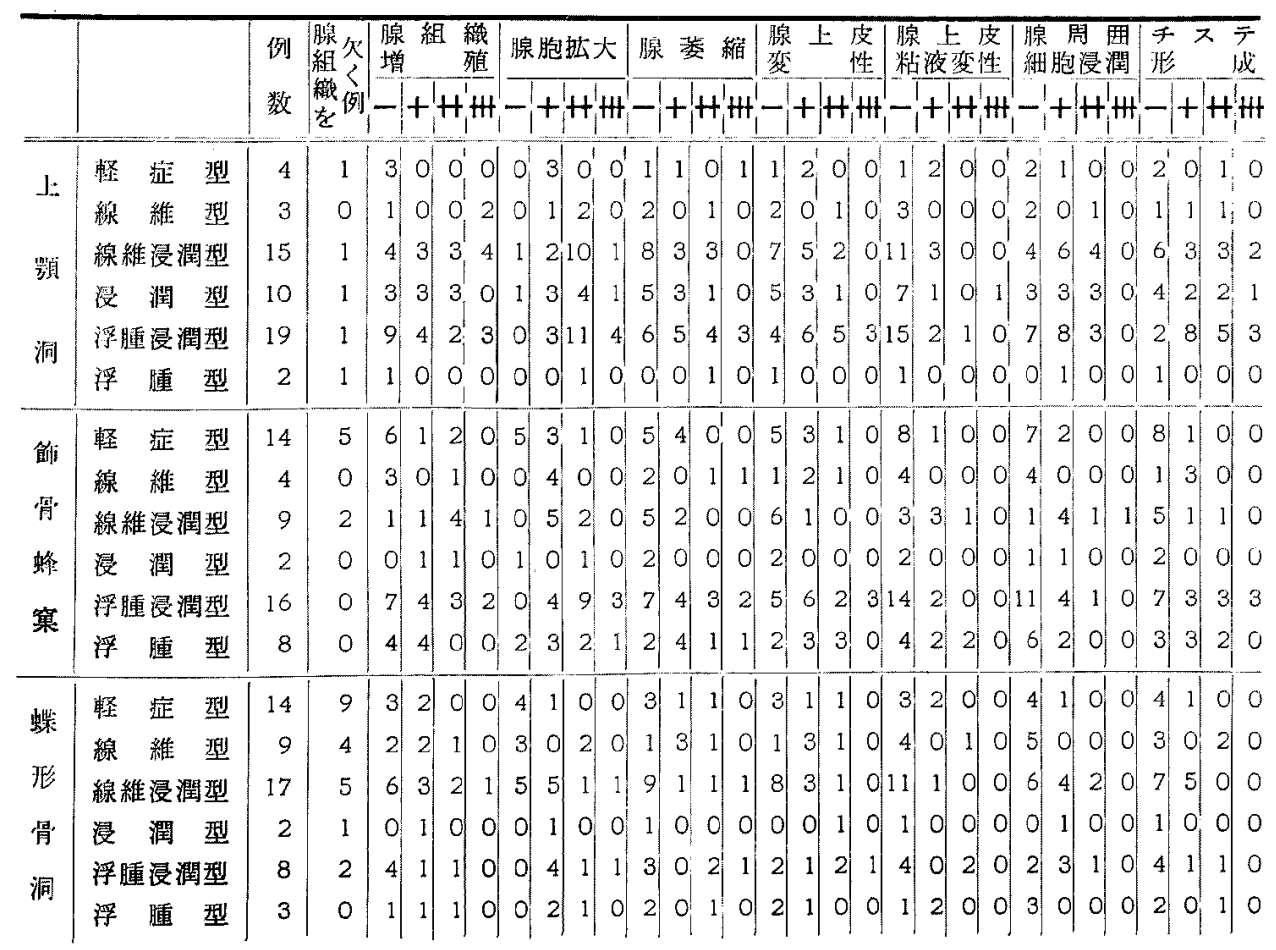


第 6 表 血 管 $の$ 変 化

\begin{tabular}{|c|c|c|c|c|c|c|c|c|c|c|c|c|c|c|c|c|}
\hline & & & & & & & & & Iflit & 跑" & & 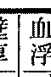 & 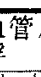 & 腫 & & 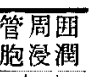 \\
\hline & & & & & & & & & & & & & & & & + \\
\hline & 徒型 & & 2 & & 1 & 3 & $\mathbb{1}$ & 0 & 1 & 1 & 1 & $0|3|$ & 1 & of 0 & 4 & $0_{1}^{\prime} \quad 0^{\prime}$ \\
\hline & 線 維 狂 & & 2 & 0 & 1 & 2 & 1 & 0 & o & 2 & 1 & 12 & 1 & 00 & 3 & 0 \\
\hline 98 & 線 維漫浧型 & & 1 & 8 & 3 & 5 & 6 & 2 & 5 & 0 & 2 & 0,13 & 2 & 00 & 14 & 0 \\
\hline & 型 & 10 & 3 & 1 & 3 & 1 & 2 & 4 & 4 & 5 & 5 & & $1)$ & 00 & 8 & 20 \\
\hline & 浮腱浸潤型 & 19 & 1 & 6 & 8 & 3 & 6 & 5 & 511 & 3 & 3 & 0,17 & 2 & 0 & 16 & 0 \\
\hline & 开 & & $0_{1}^{\prime}$ & & 1 & 0 & 2 & 0 & 2 & 6 & 1 & & $0_{1}$ & & 2 & \\
\hline & 症 型 & & & & 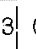 & 2 & 1 & 1 & 8 & 5 & 1 & & d & & 14 & \\
\hline & 線 維 型 & & 3 & & o & 4 & $O^{\prime}$ & 0 & 1 & 1 & 2 & 04 & o & 00 & 4 & 0 \\
\hline & 線維浸湎型 & & 6 & l & 2 & 5 & 3 & 1 & 1 & 5 & 3 & 06 & 2 & 10 & 9 & 0 \\
\hline 峰 & 浸 閵 型 & 2 & 0 & 1 & 1 & 0 & 2 & 0 & 1 & o & 1 & 2 & 0 & 00 & 2 & 0 \\
\hline 窗 & 浮揰浸 & & 8 & 2 & 6 & 8 & 5 & 2 & 7 & 6 & 3 & 015 & 1 & 0 & 6 & 0 \\
\hline & 腄 & & & & ? & & & 0 & 5 & 3 & c & 7 & 1 & 0 & 7 & \\
\hline & 症 型 & & & & & 2 & & $0 !$ & 4 & 8 & 2 & 4 & 0 & & 2 & $20_{1}^{1} 0$ \\
\hline & 維 型 & & & & & 6 & & 0 & 3 & & 1 & 1) 7 & 2 & o 0 & 0 & 3 \\
\hline & 線稚浸潤型 & & & & u & 11 & & 2 & & 3 & 0 & 012 & 4 & 1 & 16 & 1 \\
\hline 骨 & 潤 & & 0 & & & 1 & 0 & & 4 & 0 & ] & 1 & 0 & 1 & 2 & 0 \\
\hline & 浮揰浸潤型 & & 2 & & & 4 & & & 5 & 2 & 1 & 7 & 1 & & 5 & 3 \\
\hline & 随 & & & & & & & & & 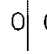 & & & 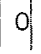 & & 8 & \\
\hline
\end{tabular}

がこれに次いでいることは成書に記す所 である.著者の例抽いても主として淋 巴球と形質細胞の相対関係を锥祭するこ と〉，アレルギーと密接な関倸があると

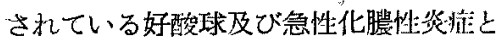
関係があるとされている好中球の出現頻 度を得ることを目的として平均 100 分率 を作つた(表?)，(表8)。

洙巴球は各副鼻腔の各病型を通して最 も多数出現して扣り，上皮下より梁層に わたつて存在し，時としてリンパ濾胞を 形成する. 形質細胞の出現の強い粘膜で はリン八球の出現比率が減少している。 焱定が軽く浸潤細胞の少ない軽症型, 線 維型においてては淋巴球の出現率が增加与 る.そのためこれらの病型の多い蝶形骨 洞では淋巴球の出現が最も高度となつ た。

形質細胞は淋巴球に次いで多く認めら れる。淋巴球とは逆に上顎洞粘膜におい て最も高く, $32.2 \%$, 次いで節骨蜂集 $26.6 \%$ ，蝶形骨洞では最子低く $24.3 \%$ は血管中膜の肥厚であつて，高血圧症に括けるように閉 膜の肥临は認められなかつた，蝶形骨洞の粘償では血管 壁の肥厚が特徽的であり，こ机はこの洞の粘償が線維增 殖が強いためによるものと思えれる。

f）蝶形尚洞粘点の浸潤継胞について

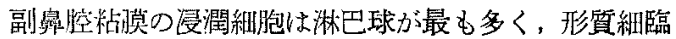

第 7 表 各洞粘膜の浸潤細胞 100 分率

\begin{tabular}{|c|c|c|c|c|}
\hline & 淋匹球 & 形質細胞 & 好酸球 & 好中球 \\
\hline 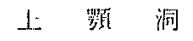 & 62.4 & 32.2 & 3.3 & 2.1 \\
\hline 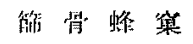 & 69.1 & 26.6 & 2.8 & 1.5 \\
\hline 蝶 形 骨 洞 & 71.6 & 24.3 & 1.7 & 2.3 \\
\hline
\end{tabular}

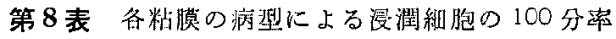

\begin{tabular}{|c|c|c|c|c|}
\hline & 淋区球 & 犻質細胞 & 好酸球 & 好中球 \\
\hline 柽 症 型 & 77.6 & 17.8 & 1.1 & 1.5 \\
\hline 線 維 型 & $79 \%$ & 18.9 & 1.1 & 0.9 \\
\hline 楾稚浚澌些 & 74.2 & 21.7 & 2.3 & 1.8 \\
\hline 设 潤 型 & 59.7 & 32.0 & 5.0 & 3.3 \\
\hline 浮腫 漫湖型 & 55.1 & 39.2 & 3.6 & 2.1 \\
\hline 浮偊型 & 54.2 & 39.6 & 3.4 & 2.7 \\
\hline
\end{tabular}
潤型，線維浸润型，線稚型と出現染が低下し，軽泟型が 最も但い、一般に炎症の強い例に执いて出現率が高い。

好酸球の浸潤は粘膜の浮腫, 結合織及び血管壁の線維 素性膨化と共にアレルギー反応の特解とされている。漖 者の例では $1 \%$ 以上が上䓏洞では 53 例中 25 例，篩骨婎 菓では 32 例，蝶形骨洞では18 例であり，10\%以上の

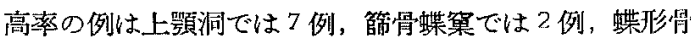
洞では 1 例であつた。病型別に見ると浸潤型に最も高く $5.0 \%$ ，浮腫浸潤型 $3.6 \%$ ，浮腫型 $3.4 \% ，$ 線維浸潤垤 2.3 $\%$ ，線維型と軽症型が最も低く $1.1 \%$ となつた．炎症の 激しい上顎洞に和いて出現率が最も嵪い，外部の刺㦸を 受け易い位置にあることが誘因となるのではないかと考 壳られる。

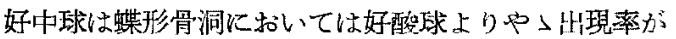
高いが他の洞では低い，病型別では漫润型で最む滴く， 線維型で最も低い，浮腆の强い型に多く，好磪球と同じ ような傾向が見られる，炎庭の強さと関連性があるので はないかと思われる。
となつている、病別に見ると，浮腫型，浮腫浸潤型，浸 


\section{2. 蝶形骨洞粘膜の病型と上䅡洞及び 蝶骨蜂窭の粘膜の病型との比較}

蝶形骨洞と上颚洞及び節骨蝶巢との病变の程度につい ては，臨床的に竹本は上颚洞が最も病变が強く，節骨蝶 集，蝶形骨洞と哚部に向らに従つて病変が軽度となると した. 著者の例に执いてる既に述へたように，上顎洞が

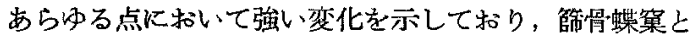
蝶形骨洞ははるかに变化が軽度であるが，同一琁例にっ

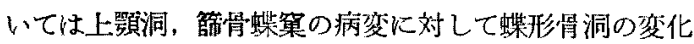
がどのよらな推移をするるのかを見るために，各症例に ついて上顎洞，篩骨蝶柋の各々の病型の例が蝶形骨洞で はいかなる病型を示すか分類した。

上䋶洞との関保においては（表9）に示すように，上 䫟洞が軽症型, 又は線維群（線維型+線維浸潤洞型）の 例で恃蝶形骨洞の病型も大部分が 軽症型か 線維群であ る.上頻洞が浮腫群（浮腫型+浮腫浸潤型）の例の蝶形 骨洞においても，約 $2 / 3$ 近くの例は線維群力又心軽症型 を示しており，21 例中 8 例のみが浮腫群であつた。し かし逆に蝶形骨洞が浮腫群に属する例の上顎洞粘膜はほ とんど大部分が浮腫群であることがわかつた。

第9 表上䫓洞之蝶形骨洞の粘膜病䍿の此較

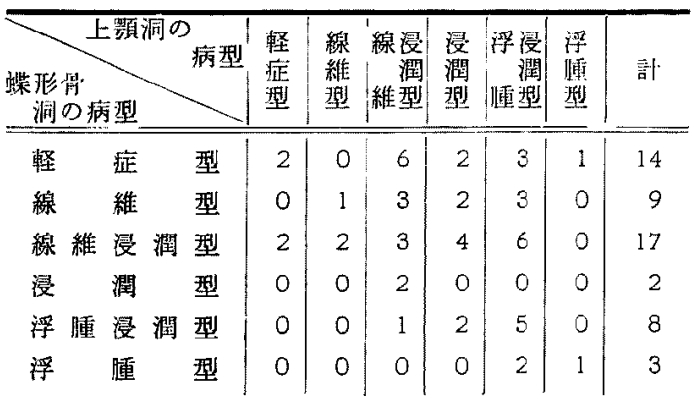

上頻洞がが浸潤型のように強い变化を示す10例でも， 蝶形胃洞では軽拉型 2 例, 線維型 2 例, 線維浸潤型 4 例 となり，浸潤は軽くなり，線維の增殖が強くなつてくる ので特接である。

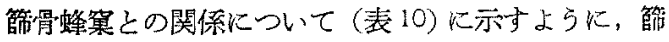

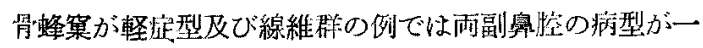
致する例が 27 例中 19 例を示している，籍骨蜂巢が浮蕾

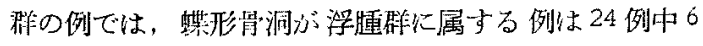
例となり $1 / 4$ の例しか一致していない，即ち炎怔の程度

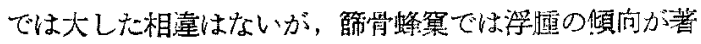
明であり，蝶形胃洞では結合繶線䌖の增殖の傾向が強く 現われている。

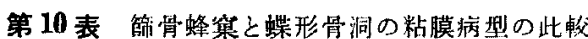

\begin{tabular}{|c|c|c|c|c|c|c|c|c|c|}
\hline $\begin{array}{l}\text { 蝶形咀 } \\
\text { 洞の将 }\end{array}$ & 具蜂穿 & 离型 & $\begin{array}{l}\text { 俥圣 } \\
\text { 望 } \\
\text { 型 }\end{array}$ & $\begin{array}{l}\text { 線 } \\
\text { 維 } \\
\text { 型 }\end{array}$ & $\begin{array}{l}\text { 線漫 } \\
\text { 潤 } \\
\text { 維型 }\end{array}$ & $\begin{array}{l}\text { 浸 } \\
\text { 潤 } \\
\text { 型 } \\
\end{array}$ & 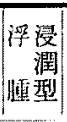 & $\begin{array}{l}\text { 滛 } \\
\text { 䏦 } \\
\text { 型 }\end{array}$ & 部 \\
\hline 垓 & 症 & 型 & 9 & 1 & 1 & 0 & 2 & 1 & 14 \\
\hline 線 & 維 & 型 & 1 & 1 & 2 & 0 & 1 & 4 & 9 \\
\hline 線 維 & 漫 潤 & 梨 & 2 & 1 & 6 & 0 & 8 & 0 & 17 \\
\hline 浸 & 潤 & 羿 & o & 0 & 0 & 0 & 2 & 0 & 2 \\
\hline 浮 $\|$ 雨 & 浸 潤 & 堽 & 1 & 1 & 0 & 1 & 3 & 2 & 8 \\
\hline 浮 & 嗹 & 型 & 1 & 0 & 0 & 1 & 0 & 1 & 3 \\
\hline
\end{tabular}

\section{3. 総括並びに考按}

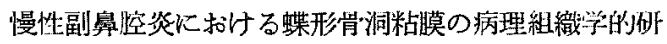
究に和いて，竹本は386洞中 330 洞 (85.5\%) 飞漫性桨 症を証明し, 他洞の病变と同様に慢性カタル型, 稩胞浸 潤型, 線維型混合型の 4 型に区別し，その約半数は線維 型を示し，次いでカタル型が多く浸潤型は稀であつたと した. 著者の例においても蝶形骨洞粘膜の反応は上顎洞

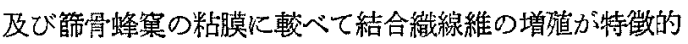
な変化であり，そのため粘膜の病型としては線維型及び 線維浸潤型が極めて多く，49\%を占めていることがかか つた．乙か乙全例の $1 / 4$ に相当寸る 14 例（26\%）は粘 膜の変化が軽度で病型をはつきり決定することの出来な い軽症型であり，炎症の強い浸潤型は稀で僅か3.8\%で あつた，蝶形骨洞粘膜では線維の增殖と共に变化が比較 的に軽いことも特徵的である.

この線維型及び線維浸潤型とい5病型は慢性副鼻腔炎 の病型の分頑上か形曼性炎症の陳休型とされて初り, 吉 村はなんらかの原因に上り副鼻腔の粘膜に浮腫が起り， それ感染が加わつて炎性細胞の浸㵎が起り, やがて治 痹すると結合組織の垻殖が起るのであるが，別の機会代 又再発して同様の経過を反復するとした，加滕も吉村の 説を支持して炎泟は動的な過程であって静止した状態で はないとし，炎柾といら流れの中で変化寸る粘膜形態像 の代㤗的なものとして, Manasse の浮腫型, 漫潤型, 線 維型を認めて, 浮腫型 $\rightarrow$ 漫潤型十浮腫型 $\rightarrow$ 浸潤型一浸潤 型十線稚型一線維型といら病型を分類して, 線維性肥厚 を炎淀の帰結した型とした。美も浮腫型より線維型に变 化するとのべている. 阿部及び牟田は Pnenmatisrtion の近埸加副奥临の一つの局所的素因として，外部の刺

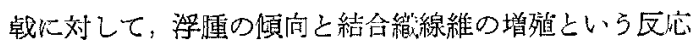
を持つとし，この素因は含父腔である副鼻绫の発育の程 度に上るとし，又この素因は終企柗らないとした， 
蝶形骨洞は形態の上からは上顎洞と類似した洞で，洞 非成 (Höblers bildung) が主で，小胞形成（zellen bildmg）の極めて弱い含気腔であるが，粘膜の反応は 異つている. 粘膜の反応は洞の形態とともに丵成骨によ つても異つていることを示している。この点から考党る と炎婝に影響する局所的条件は粘膜下骨壁の厚さに第一 我的な意義があるのではないかとる見られる。粘膜下の 骨壁の厚さは他の洞ではその洞の大きさに関俰している が，蝶形骨洞の場合はこの骨の構成上洞が大きくてもな ほかなりの厚さの骨壁よりなつていることが他の洞と異 る点である.そのため蝶形骨洞は洞の素因として線維性 の反応を持つことが大であると思われる。

\section{4. 結 語}

53 例の慢性副鼻腔绻者について，蝶形骨洞粘膜の 病装を組織学的に観察し，同一例の上顎洞及び節骨蜂窂 の粘膜の病変と比較䂙究した。

1) 柴形骨润の粘膜は結合織線維の增殖の傾向が他の 副學腔の粘膜と比較して著明である。そのため粘膜の病 型としては線維型，線濰浸潤型の例が26例 (49\%)であ つた.

2) 蝶形目洞粘膜に蛙いては炎症変化が軽度で肥厚も

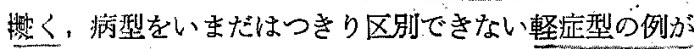
14 例 $(26.4 \%)$ であつた。この軽症型の頻度は節骨蜂 窠, 前頭洞とほら゙一致している。

3) 蝶形骨洞粘膜の細胞浸潤の程度（即ら炎怔の強さ）

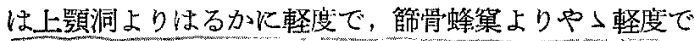
ある.

4) 蝶形骨洞粘膜の血管は 充血及び毛組管新生の像は 他の副鼻腔粘莫与り少ないが，血管壁の肥厚が特に强 W.

5)新形骨洞粘膜の腺組識は他の副鼻腔粘膜より少数 であり，腺萎縮，上皮变性度の退行性変化の傾问が強 々，チステの形成が少ない。

6) 蝶形骨洞粘膜の浸潤細胞の平均 100 分比は淋巴现 $61.6 \%$ ，形留細胞 $24.3 \%$ ，好聡球 $1.7 \%$ ，好中球 $2.3 \%$ で
あつた，淋巴球は3種の劇烅腔のうち最す出現察が高 く，形質稩胞と好酸球恃出現率が最も低い。

7) 上颚洞粘膜の病型が線維群（線維型十線維浸潤洞 型）の例の蝶形骨洞粘膜の病型は大部分が軽症型か線維 群であり，上㖽洞粘膜の病型が浮腫群（浮腫型十浮膜浸 潤型）の例に括いてを，蝶形骨洞粘膜の病型は約 $2 / 30$ 例が軽症型若しくは線維样であつた，上颢洞粘膜が浸潤 型の例に执いてす，蝶形骨洞の变化は軽度であり，線維 の增殖加強い。

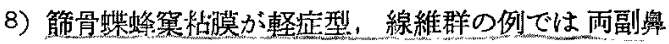
腔の病型がー一致する例が多く，軽症型では 14 例中 9 例，

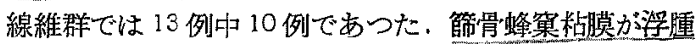
群の例では約 $1 / 4$ 例しか一致しなかった。

\section{主 要 文 献}

1) 後藤 (敏): Pneuma tisation の成立とその臨床, 日耳焉，56：217，1028，1953，2）松村・竹本：上顎 経由に上る楔状洞手術 200 例の経歌（学会抄），日耳舆， 58：160,1955.3）阿部：慢性副奥腔炎に括りる副聯 膑 Pneumatisation と粘膜及び骨壁の病変との関係につ いて，日耳奥，58：476，1955。4) 年田：慢性副鼻膑 炎と副鼻腔 Pneumatisation との関係に就いての研究補

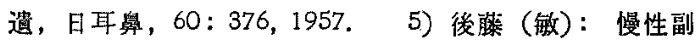
鼻腔炎治療の根本的態度，耳囟臨，51:47, 1958, 6)

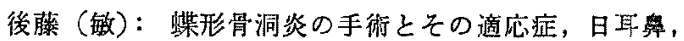
$62 ： 1536 ， 1959.7$ 7) 高須贺・隅上：上㯰洞粘模の舅 物反必に就て，(学会抄)，日正岁，62：1660，1959．8）

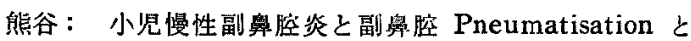
の関係に就いての研究，日耳奥，62：2037，1959，9） 竹本：上颚洞経由蝶形骨洞開放術に関寸る研究，日耳

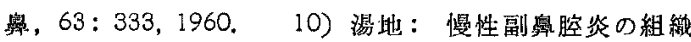

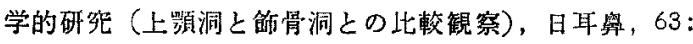
1658, 1960.11）龟本・高須資：含気腔学説よりみた 前頭涯の組織学的研究，日耳鼻，63：2156, 1960.

（原稿到着＝昭 $36.2,17$ 日） 